\title{
Preliminary Characterization of a Cellulase Producing Bacterial Strain Isolated from a Romanian Hypersaline Lake
}

\author{
Robert Marian Ruginescu${ }^{1}$, Roxana Cojoc ${ }^{1}$, Mădălin Enache' ${ }^{1}$, Veronica Lazăr ${ }^{2}$ \\ ${ }^{1}$ Institute of Biology Bucharest, Romanian Academy, Bucharest, Romania \\ ${ }^{2}$ Botany-Microbiology Department, Faculty of Biology, University of Bucharest, Bucharest, Romania \\ Email: robert.ruginescu@ibiol.ro
}

How to cite this paper: Ruginescu, R.M., Cojoc, R., Enache, M. and Lazăr, V. (2018) Preliminary Characterization of a Cellulase Producing Bacterial Strain Isolated from a Romanian Hypersaline Lake. Journal of Environmental Protection, 9, 1066-1081. https://doi.org/10.4236/jep.2018.910066

Received: July 26, 2018

Accepted: September 4, 2018

Published: September 7, 2018

Copyright $(9) 2018$ by authors and Scientific Research Publishing Inc. This work is licensed under the Creative Commons Attribution International License (CC BY 4.0).

http://creativecommons.org/licenses/by/4.0/

\section{(c) (i) Open Access}

\begin{abstract}
Cellulases are a group of enzymes that are used in many biotechnological processes. Since most of the enzymes synthesised by mesophilic microorganisms are unstable in industrial environments, it is necessary to direct research towards extremophile cellulolytic microorganisms because the enzymes synthesised by them are stable and active even in harsh physicochemical conditions. In the present investigation, our aim was to isolate and identify some microbial cellulolytic strains from a hypersaline lake located in Romania and to determine their optimal growth conditions. Of a total of 25 microbial strains isolated, only one extreme halotolerant bacterial strain was able to produce an endoglucanase. Based on molecular identification, we identified this cellulolytic strain as a species of Bacillus genus, most closely related to Bacillus zhangzhouensis. Optimal growth conditions were found to be at $15^{\circ} \mathrm{C}, \mathrm{pH} 7.5$ and $2 \mathrm{M} \mathrm{NaCl}$. Endoglucanase activity of this bacterial strain is influenced by both salinity and temperature. The most significant endoglucanase activity was detected in the presence of $3 \mathrm{M} \mathrm{NaCl}$, after $72 \mathrm{~h}$ of incubation at $15^{\circ} \mathrm{C}$. In this situation, the amount of glucose released from a volume of $0.5 \mathrm{~mL}$ of $2 \%(\mathrm{w} / \mathrm{v})$ carboxymethyl cellulose substrate is equivalent to $2.05 \mathrm{mg}$. In conclusion, this study represents the first preliminary characterization of a $B$. zhangzhouensis strain that has the ability to degrade cellulose and that demonstrates tolerance to high salt concentrations.
\end{abstract}

\section{Keywords}

Cellulases, Cellulose Residues Bioconversion, Cellulolytic Bacterial Strain, Hypersaline Lakes, Salt-Tolerant Enzymes 


\section{Introduction}

Cellulose is the primary constituent of the plant cell walls and the most abundant renewable biological compound on Earth [1] [2]. It is estimated that more than $10^{11}$ tons of this polysaccharide are synthesized each year on our planet by photosynthesis [2] [3].

Cellulose is a polydisperse, linear, syndiotactic polymer that consists of $\beta$-1,4-linked glucosyl units. Despite its simple chemical composition, the supramolecular structure of cellulose is very complex due to multiple intra- and intermolecular hydrogen bonds. This extensive hydrogen bond network is responsible for the compactness of the cellulose chains, which result in the rigidity of the cellulose fibrils and their high mechanical resistance and to chemical attack [1] [3]. In this regard, cellulose fibrils have a tensile strength comparable to steel [4] and they are both insoluble in most solvents and hard to be enzymatically hydrolysed to glucose [1] [5].

In the environment, cellulosic residues resulted especially from the death of the primary producers are degraded by cellulolytic microorganisms, represented by fungal and bacterial strains [6] [7]. These microorganisms are able to synthesize cellulolytic enzymes, called cellulases, which are involved in the decomposition of cellulose fibrils to monomers represented by glucose. The main enzymes involved in the conversion of cellulose fibrils to glucose are endoglucanases (E.C.3.2.1.4), exoglucanases (E.C.3.2.1.176 and E.C.3.2.1.91) and $\beta$-glucosidases (E.C.3.2.1.21). The complete depolymerisation of cellulose requires the synergistic action of all three types of enzymes [6] [8] [9] and this process provides the opportunity for exploiting the cellulosic waste (particularly agro-alimentary waste) as an abundant and inexpensive carbon source [10].

Since the cellulolytic microorganisms are involved in the decomposition of cellulosic residues, they play an essential role in the terrestrial carbon cycle [7]. On the other hand, microbial cellulases have shown their biotechnological potential in many industries, such as: textile, food processing, wine and brewery, detergent, animal feed, pulp and paper, biofuel, pharmaceutical, agricultural industries, waste management and so on [9] [11] [12] [13]. Therefore, due to numerous applications of cellulolytic enzymes in various industrial processes, it is very important to characterize and optimize the existing cellulases, as well as to identify new enzymes with superior properties or more suitable for some specific uses.

Recent scientific studies have shown that cellulolytic enzymes produced by mesophilic microorganisms are structurally and functionally distinct from those synthesized by extremophilic microorganisms, the latter ones being more stable in the harsh physicochemical conditions of various industrial processes [9] [13] [14]. In this regard, it has been shown that cellulases synthesized by halophilic microorganisms have a high content of acidic amino acids which are located on the protein surface. These amino acid residues bind a large quantity of water molecules and metal ions to maintain the catalytic activity of the enzyme [15]. 
Due to this structural property, cellulases produced by halophilic microorganisms exhibit an increased resistance in the extreme salinity conditions of biotechnological processes, thereby enhancing their efficiency [10] [16].

Since there is a relatively small number of scientific researches dedicated to halophilic cellulolytic microorganisms, the purpose of the present investigation was to test the cellulolytic potential of the halophilic microbial strains isolated from a Romanian hypersaline lake and to make a preliminary phenotypic and genotypic characterization of a selected cellulolytic bacterial strain.

\section{Materials and Methods}

\subsection{Sampling Site Description}

Mud samples were collected from a salted water, more precisely Movila Miresii Salt Lake located in a plain area of Brăila County, Romania (GPS coordinates: N $45^{\circ} 13^{\prime} 14.62^{\prime \prime} / \mathrm{E} 27^{\circ} 38^{\prime} 31.58^{\prime \prime}$ ) (Figure 1). Samplings were carried out in July 2016 from a distance of about 15 meters from the shore, the water depth in the area being $70-80 \mathrm{~cm}$. The saline mud samples were collected in sterile plastic containers and were stored at $4^{\circ} \mathrm{C}$ before analysis. The temperature and $\mathrm{pH}$ of the sampling site water were $27^{\circ} \mathrm{C}$ and 9.4, respectively.

\subsection{Bacterial Isolation and Screening for Cellulase Activity}

The halophilic microbial strains were isolated by serial dilution plating technique on moderately halophiles growth medium $(\mathrm{MH})$ containing: glucose $(1 \mathrm{~g})$, proteose-peptone $(5 \mathrm{~g})$, yeast extract $(10 \mathrm{~g}), \mathrm{NaCl}(100 \mathrm{~g}), \mathrm{MgCl}_{2} \cdot 6 \mathrm{H}_{2} \mathrm{O}(7 \mathrm{~g})$,

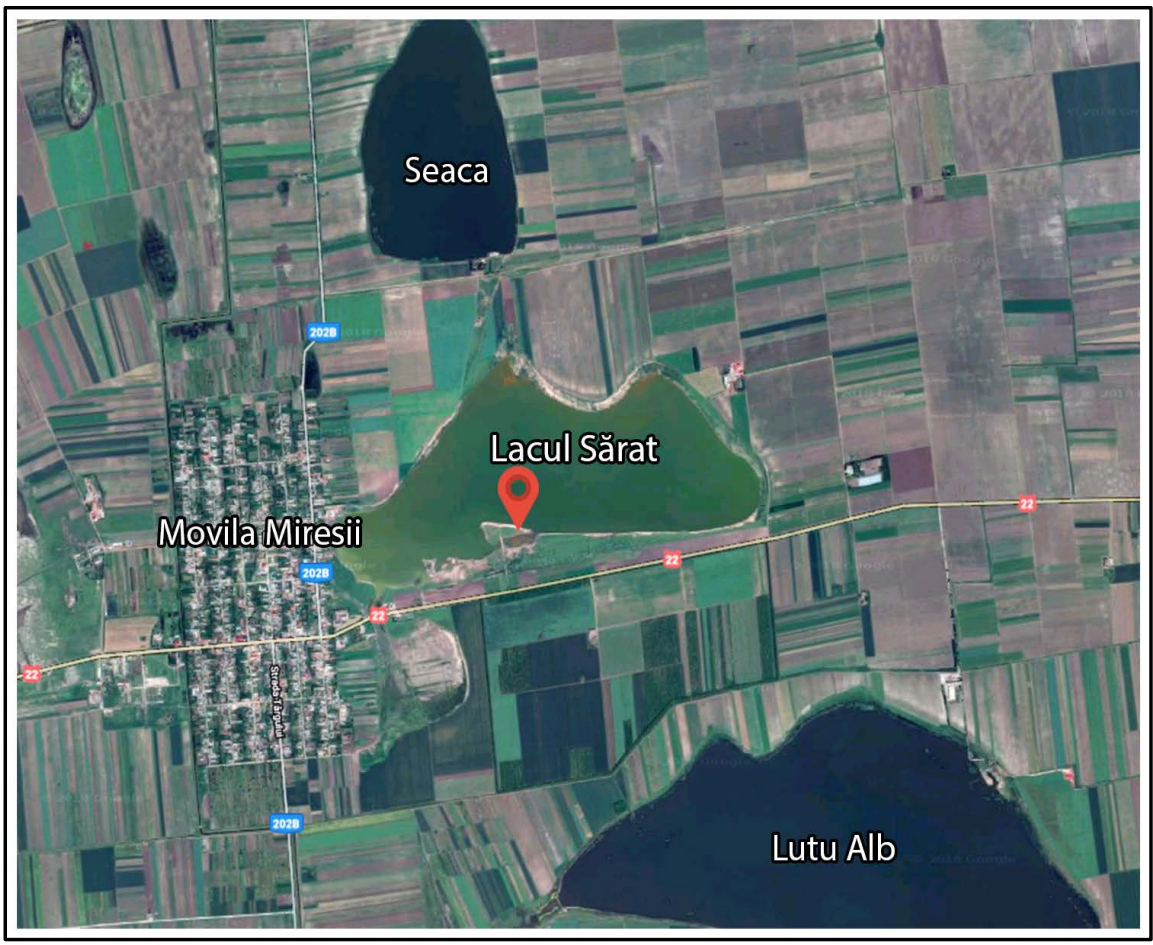

Figure 1. Representation of the geographical location of Movila Miresii Salt Lake. 
$\mathrm{MgSO}_{4} \cdot 7 \mathrm{H}_{2} \mathrm{O}(9.6 \mathrm{~g}), \mathrm{CaCl}_{2} \cdot 2 \mathrm{H}_{2} \mathrm{O}(0.36 \mathrm{~g}), \mathrm{KCl}(2 \mathrm{~g}), \mathrm{NaHCO}_{3}(0.06 \mathrm{~g}), \mathrm{NaBr}$ $(0.026 \mathrm{~g})$ and agar $(20 \mathrm{~g})$ in $1000 \mathrm{~mL}$ distilled water [17] [18]. The growth medium $\mathrm{pH}$ was adjusted to 7.2 before autoclaving $\left(30 \mathrm{~min}, 120^{\circ} \mathrm{C}\right)$. The plates were incubated at $30^{\circ} \mathrm{C}$ for 7 days and the bacterial strains were purified by streak plate method. The purified microbial strains were preserved at $4^{\circ} \mathrm{C}$.

For screening cellulase producers, the microbial isolates were grown in $\mathrm{MH}$ medium supplemented with varying concentrations of carboxymethyl cellulose (CMC: $0.5 \%, 1 \%, 1.5 \%, 2 \%, \mathrm{w} / \mathrm{v}$ ), as sole source of carbon. Bacterial strains were inoculated in triplicate wells and the experiment was repeated three times. The plates were incubated at $30^{\circ} \mathrm{C}$ for 5 days. After this period, the agar growth medium was flooded with an aqueous solution of Congo Red (1\%, v/v) for $30 \mathrm{~min}$. Further, to visualize the zones of CMC hydrolysis, formed by cellulase positive strains, the Congo Red solution was poured off and the plates were destained by flooding with $1 \mathrm{M} \mathrm{NaCl}$ solution for at least $15 \mathrm{~min}$ [19]. The bacterial strain which produced a zone of clearing around the colonies was selected for further investigations.

\subsection{Cultural, Morphological and Biochemical Characterization of the Cellulolytic Strain}

Cultural characteristics of the cellulase producing strain were determined by culturing it on solid MH medium. Morphological characteristics were studied by wet mount preparations and Gram staining.

The ability of the investigated strain to produce extracellular hydrolytic enzymes was tested on $\mathrm{MH}$ basal medium (without glucose and proteose-peptone) supplemented with an appropriate substrate (1\% casein, $15 \%$ gelatine, $1 \%$ pectin, $0.1 \%$ Tween $80,1 \%$ starch, $0.2 \%$ inulin) [20] [21]. All the plates, except the medium with gelatine, were incubated at $30^{\circ} \mathrm{C}$ for $72 \mathrm{~h}$. Gelatine medium was incubated at $30^{\circ} \mathrm{C}$ for 7 days and at the end of this period the tubes were maintained at $4^{\circ} \mathrm{C}$ for $30 \mathrm{~min}$. Gelatine liquefaction indicates the enzymatic hydrolysis of this compound and therefore the ability of the strain to produce gelatinase [22]. In the case of the growth mediums with casein, pectin and starch, the presence of a clear area surrounding the microbial colonies indicates a positive reaction (the ability of the strain to produce caseinase, pectinase and amylase) [20] [21]. The lipolytic activity of the strain was indicated by the precipitation, as calcium salts, of the fatty acids released by hydrolysis of the Tween 80 compound [23]. Inulinase activity was shown by the ability of the microbial strain to grow on the medium supplemented with inulin, as the sole source of carbon [20].

Catalase assay was performed using $\mathrm{H}_{2} \mathrm{O}_{2}$ as substrate [22] and the presence of the enzyme cytochrome c oxidase was tested by Kovacs method [24]. Indole test and hydrogen sulphide $\left(\mathrm{H}_{2} \mathrm{~S}\right)$ production test were performed according to the methods described by Holding and Collee [25].

Membrane phospholipid profile was determined by thin layer chromatography (TLC), using a stationary phase represented by a glass plate, coated with a 
thin layer of silica gel, and a mobile phase represented by a solvent mixture (chloroform:methanol:acetic acid:water, in the following proportions: 85:22.5:10:4, $\mathrm{vol} / \mathrm{vol} / \mathrm{vol} / \mathrm{vol}$ ). The plate was sprayed with dodeca-molybdophosphoric acid $10 \%$ in ethanol for the detection of phospholipids [26].

\subsection{Molecular Identification of the Cellulolytic Strain}

The molecular identification of the cellulase producing bacterial strain involved the isolation of genomic DNA, PCR amplification of the 16S rDNA gene and its sequencing.

Bacterial DNA was extracted using the NucleoSpin ${ }^{\circledR}$ Tissue (Macherey-Nagel) kit. 16S rDNA sequence was amplified from extracted DNA using the following primers [27]: 27F (AGAGTTTGATCACTGGCTCAG) and 1492R

(ACGGCTTACCTTGTTACGACTT). The reaction was carried out in $25 \mu \mathrm{l}$ volume, containing: $2.5 \mu \mathrm{l}$ PCR buffer (Master Mix), $1 \mathrm{mM} \mathrm{MgCl}, 0.2 \mathrm{mM}$ dNTP, $0.4 \mu \mathrm{M}$ of each primer, 1.25 U Taq DNA polymerase, $16.8 \mu \mathrm{l}$ Milli-Q water, $1 \mu \mathrm{l}$ DNA. PCR was performed in a thermocycler (Eppendorf Mastercycler pro $S$ ) with the following programme: 2 min denaturation at $95^{\circ} \mathrm{C}$, followed by 35 cycles of $30 \mathrm{~s}$ denaturation at $95^{\circ} \mathrm{C}, 30 \mathrm{~s}$ annealing of primers at $54^{\circ} \mathrm{C}, 90 \mathrm{~s}$ extension at $72^{\circ} \mathrm{C}$, and a final extension step of $5 \mathrm{~min}$ at $72^{\circ} \mathrm{C}$. The amplicons were tagged with Red Safe and then visualized by electrophoresis in 1\% (wt/vol) agarose gel. To verify the molecular size of the amplicons, $1 \mathrm{~Kb}$ DNA Ladder molecular weight-size marker (New England Biolabs) was used. PCR product was purified using the PureLink ${ }^{\oplus}$ PCR Purification (Invitrogen) kit and then was sent for sequencing to CeMIA SA (Larissa, Greece). The nucleotide sequence obtained was compared with the NCBI database using BLASTN

(https://blast.ncbi.nlm.nih.gov).

\subsection{Characterization of the Optimal Growth Conditions}

To determine the optimal growth temperature of the cellulolytic strain, it was cultured in liquid $\mathrm{MH}$ medium. Samples were incubated at different temperatures $\left(4^{\circ} \mathrm{C}, 15^{\circ} \mathrm{C}, 20^{\circ} \mathrm{C}, 30^{\circ} \mathrm{C}, 37^{\circ} \mathrm{C}, 45^{\circ} \mathrm{C}\right)$ in thermal shakers and the absorbance (OD) was measured at $660 \mathrm{~nm}$ and $24 \mathrm{~h}$ intervals using a microplate spectrophotometer (FLUOstar Omega, BMG Labtech).

The potential of the cellulolytic strain to grow in the presence of varying concentration of salt was assessed by both a qualitative and a quantitative experiment. The protocol of the qualitative experiment was based on the cultivation of the bacterial strain on $\mathrm{MH}$ solid media with the following $\mathrm{NaCl}$ concentrations: $0 \mathrm{M}, 1 \mathrm{M}, 2 \mathrm{M}, 2.5 \mathrm{M}, 3 \mathrm{M}, 3.5 \mathrm{M}, 4 \mathrm{M}$, and $5 \mathrm{M}$. Agar plates were inoculated in the center of the plate, using a solid inoculum. The plates were incubated at $30^{\circ} \mathrm{C}$ for 10 days. Regarding the quantitative experiment, the bacterial strain was cultured in liquid $\mathrm{MH}$ medium with the above mentioned salt concentrations. Culture mediums were inoculated with $100 \mu \mathrm{L}$ fresh liquid inoculum $(24 \mathrm{~h})$. Samples were incubated at $30^{\circ} \mathrm{C}$ and the absorbance (OD at $660 \mathrm{~nm}$ ) was measured at $24 \mathrm{~h}$ intervals using a microplate spectrophotometer. 
Influence of $\mathrm{pH}$ on the bacterial growth was determined by the cultivation of the strain on $\mathrm{MH}$ media with different $\mathrm{pH}$ values $(5,5.5,6.0,6.5,7.0,7.5,8.0$, 8.5, 9.0, 9.5, and 10.0). The following buffer systems ( $50 \mathrm{mM}$ of each) were used: MES (pH 5.5 - 6.5), PIPES (pH 6.5 - 7.5), HEPES ( $\mathrm{pH} 7.0$ - 8.0), Tricine ( $\mathrm{pH} 7.5$ - 9.0) and CHES (pH 9.0-10.0) [28]. For $\mathrm{pH}$ adjustments were used $\mathrm{NaOH} 6 \mathrm{~N}$ or $\mathrm{HCl} 6 \mathrm{~N}$. Re-sterilization of the culture medium was done by filtration using Sartorius filters with a $0.22 \mu \mathrm{m}$ pore size. Samples were incubated at $30^{\circ} \mathrm{C}$ in thermal shakers and the absorbance (OD at $660 \mathrm{~nm}$ ) was measured at $24 \mathrm{~h}$ intervals using the microplate reader above mentioned. All experiments were performed twice.

\subsection{Endoglucanase Activity Assay}

Endoglucanase activity was determined by measuring the reducing sugars using $\mathrm{CMC}$ as the substrate. The amount of reducing sugar that was released by the enzymatic hydrolysis of CMC was estimated using the 3,5-dinitrosalicylic acid (DNS) method [29]. Reaction mixtures contained $0.5 \mathrm{ml}$ of $2 \%(\mathrm{w} / \mathrm{v}) \mathrm{CMC}$ in $0.05 \mathrm{M}$ sodium citrate buffer ( $\mathrm{pH} 4.8$ ) and $0.5 \mathrm{ml}$ of enzyme solution. Test samples and reagent blanks were simultaneously incubated in a water bath at $50^{\circ} \mathrm{C}$ for $30 \mathrm{~min}$. After boiling, the reactions were stopped by adding $3 \mathrm{ml}$ of DNS reagent to the reaction mixtures. The absorbance (OD at $540 \mathrm{~nm}$ ) of the samples was measured at $24 \mathrm{~h}$ intervals using a microplate spectrophotometer (FLUOstar Omega, BMG Labtech) and the values obtained were compared with a glucose standard curve.

The endoglucanase activity of the bacterial strain was investigated for $72 \mathrm{~h}$ under variable cultivation conditions. In this regard, the cellulolytic bacterial strain was cultured in liquid $\mathrm{MH}$ media supplemented with $0.5 \% \mathrm{CMC}$ and with different concentrations of $\mathrm{NaCl}(0 \mathrm{M}, 1 \mathrm{M}, 2 \mathrm{M}, 3 \mathrm{M})$. Incubation was carried out in thermal shakers at the following thermal values: $15^{\circ} \mathrm{C}, 20^{\circ} \mathrm{C}, 30^{\circ} \mathrm{C}, 37^{\circ} \mathrm{C}$, and $45^{\circ} \mathrm{C}$.

\section{Results and Discussion}

\subsection{Bacterial Isolation and Production of Extracellular Cellulase}

Movila Miresii Salt Lake has a natural origin and is situated in the South-East of Romania. It is well known by locals for the therapeutic effects of sapropelic mud and salty water [30]. The salinity of Movila Miresii Lake is due to the relatively high content of chloride $(80 \mathrm{~g} / \mathrm{L})$ and sodium ions $(18 \mathrm{mg} / \mathrm{mL})$. Based on these values, the lake was classified as a hypersaline ecosystem [31]. In addition, relatively high amounts of hydrogen sulphide have been identified in the sapropelic mud. This chemical compound contributes to the therapeutic properties of the mud, being produced by some species of microorganisms that populate the lake [30]. The microbiological research revealed that the concentration of microbial cells in the water samples taken from Movila Miresii Salt Lake is lower than in other environments with similar salinity. In this regard, $70 \times 10^{2} \mathrm{CFU} / \mathrm{ml}$ halo- 
philic microbial cells were identified in the samples from Movila Miresii Lake. There have also been identified species of algae from the families Bacillariophyceae and Chlorophyceae, which are responsible for the strong green colour of the lake [30] [31].

Based on the cultural characteristics and colony morphology, 25 bacterial strains were isolated from the mud samples. Of these, a single strain showed the potential to degrade CMC from the culture medium, producing circular hydrolysis areas around the wells in which it was inoculated (Figure 2). The results of the experiment (Figure 3 ) revealed that the size of the hydrolysis zone (measured from the edge of the well to the outer limit of the halo) is influenced by the concentration of CMC in the culture medium. In this respect, the increase in $\mathrm{CMC}$ concentration is correlated with the decrease in the size of the hydrolysis zone.

By the ability to synthesize extracellular cellulases, the isolated bacterial strain can survive in environments where cellulose is the sole source of carbon. The potential to hydrolyse CMC is not correlated with the ability of bacterial cells to synthesize the entire enzyme complex involved in the degradation of natural

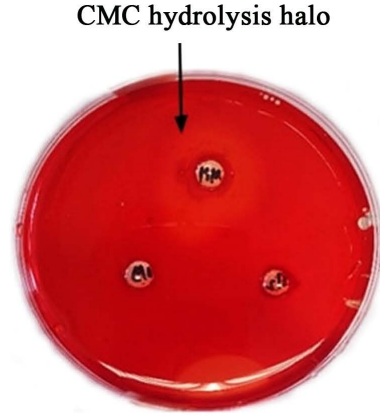

(a)

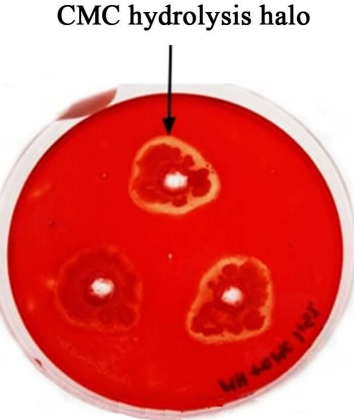

(b)

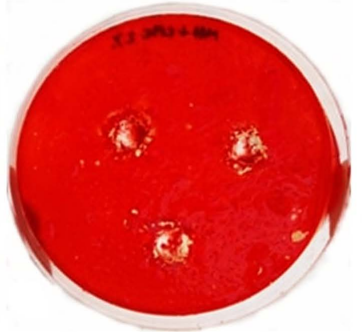

(c)

Figure 2. Zone of CMC hydrolysis produced by bacterial strain on $\mathrm{MH}$ media containing CMC after Congo-Red staining; (a) 0.5\% CMC; (b) 1.5\% CMC; (c) 2\% CMC (w/v).

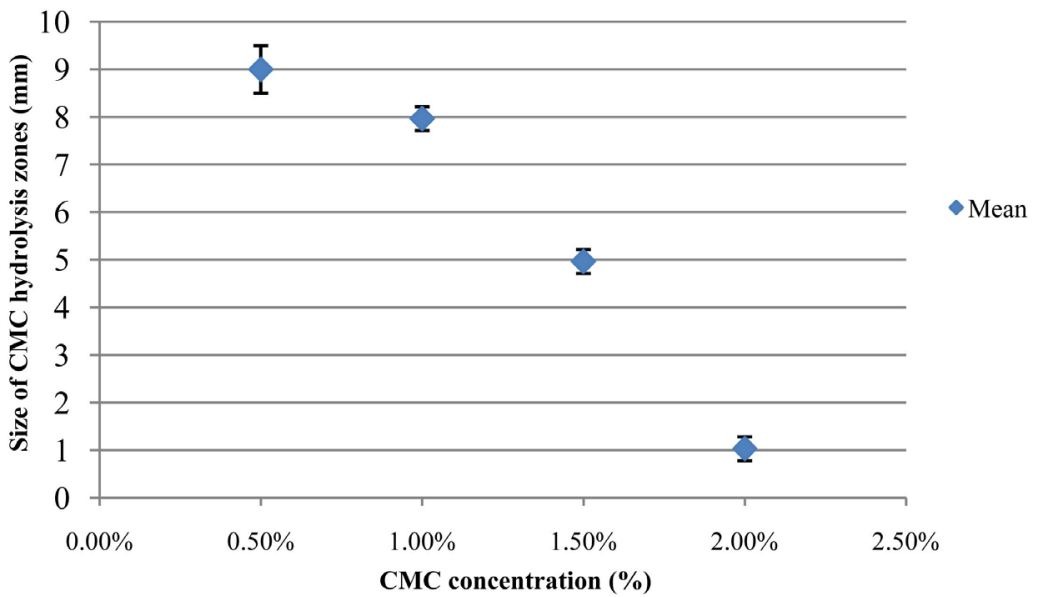

Figure 3. Influence of CMC concentration on the size of the hydrolysis zone; data represent the mean ( \pm standard deviation) of results. 
cellulose, but indicates with certainty that the strain is able to produce endoglucanase. It is quite possible that in natural environments, the identified bacterial strain could establish synergistic relationships with other cellulolytic microorganisms for complete degradation of cellulose fibres, whose supramolecular structure is extremely compact.

In the plate (a), the cellulolytic bacterial strain was inoculated only in the well marked by the arrow; in the other two wells, other non-cellulolytic bacterial strains were tested. It is assumed that in this plate, the hydrolysis zone is less visible due to the low concentration of CMC in the growth medium.

In the plates (b) and (c), the cellulolytic bacterial strain was inoculated in all three wells.

\subsection{Cultural, Morphological and Biochemical Characteristics of the Bacterial Strain}

The cellulolytic bacterial strain forms round and relatively small colonies, which are characterized by mucous consistency, white-creamy colour and glossy surface. The profile of the colonies is convex and their margins are regular. Bacterial cells are Gram positive, rod shaped and motile.

The bacterial cells showed positive reactions for catalase, oxidase, caseinase and lipase. The results of the other biochemical tests were negative (Table 1). The detailed study of enzymes that are synthesized by extremophilic microorganisms is of great biotechnological interest as it can lead to the identification of molecules with new functional properties, like the stability under the harsh conditions (temperature, $\mathrm{pH}$, salinity) of the industrial environments.

Regarding the membrane phospholipid profile, three stripes were highlighted on the TLC plate (Figure 4). According to data reported in the literature [32], the three identified retention factors $\left(\mathrm{R}_{\mathrm{f}}\right)$ correspond to three categories of phospholipids (Table 2): phosphatidylethanolamine (PE), phosphatidylglycerol (PG) and lyso-phosphatidylethanolamine (Lyso-PE).

Table 1. Results of conventional biochemical tests.

\begin{tabular}{cc}
\hline Test & Results \\
Oxidase & + \\
Catalase & + \\
Casein & + \\
Gelatine & - \\
Starch & - \\
Pectin & + \\
Tween 80 & - \\
Inulin & - \\
Indole & - \\
Hydrogen sulphide &
\end{tabular}

$(+)=$ positive reaction; $(-)=$ negative reaction . 


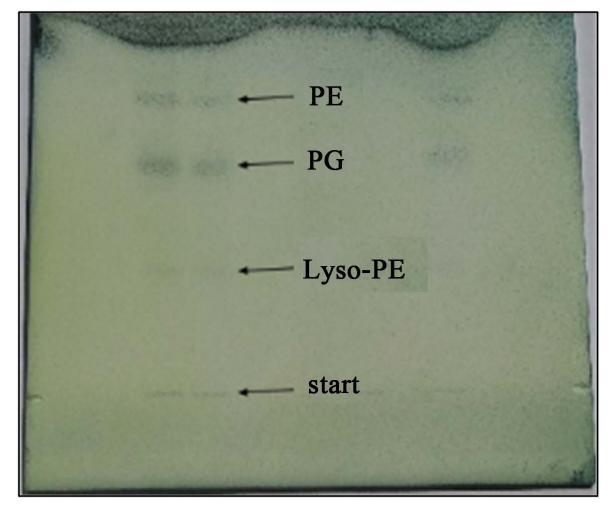

Figure 4. TLC plate: membrane phospholipid profile.

Table 2. Membrane phospholipid profile.

\begin{tabular}{ccc}
\hline Identified $\mathbf{R}_{\mathbf{f}}$ & $\mathbf{R}_{\mathbf{f}}$ in literature [32] & Lipid \\
\hline 0.64 & 0.63 & phosphatidylethanolamine (PE) \\
0.51 & 0.54 & phosphatidylglycerol (PG) \\
0.25 & 0.22 & lyso-phosphatidylethanolamine (Lyso-PE) \\
\hline
\end{tabular}

\subsection{Molecular Identification of the Strain}

Through in vitro amplification (PCR), amplicons of approximately $1.5 \mathrm{~kb}$ (Figure 5) were obtained, indicating that amplification of the gene encoding 16S rRNA was successfully performed. By comparing the nucleotide sequence obtained (Figure 6) with the $16 \mathrm{~S}$ rDNA sequences from the GenBank database (NCBI), a similarity of $100 \%$ with Bacillus zhangzhouensis strain MCCC 1A08372 (NCBI Reference Sequence: NR_148786.1) was identified. This bacterial species was described in 2016, being isolated from the water of a shrimp farm in Zhangzhou, China [33].

\subsection{Optimal Growth Conditions}

Of the 6 tested thermal values $\left(4^{\circ} \mathrm{C}, 15^{\circ} \mathrm{C}, 20^{\circ} \mathrm{C}, 30^{\circ} \mathrm{C}, 37^{\circ} \mathrm{C}\right.$ and $\left.45^{\circ} \mathrm{C}\right)$, the bacterial strain exhibits the highest growth rates at $15^{\circ} \mathrm{C}$. Significantly lower bacterial densities were identified for samples incubated at $30^{\circ} \mathrm{C}, 37^{\circ} \mathrm{C}$ and $45^{\circ} \mathrm{C}$. Generally, the stationary phase of the growth curve is reached after about $96 \mathrm{~h}$ of incubation. On the other hand, no microbial growth was detected at $4^{\circ} \mathrm{C}$ (Figure 7).

Experimental results show that the bacterial strain grows in a relatively wide temperature range: from temperatures below $15^{\circ} \mathrm{C}$ to temperatures above $45^{\circ} \mathrm{C}$. This physiological particularity is explicable if it is considered that the temperature of the lake from which the strain was isolated undergoes seasonal changes, the bacterial strain being forced to adapt to the thermal environmental changes.

By growing the bacterial strain on $\mathrm{MH}$ solid media with varying $\mathrm{NaCl}$ concentrations ( $0 \mathrm{M}, 1 \mathrm{M}, 2 \mathrm{M}, 2.5 \mathrm{M}, 3 \mathrm{M}, 3.5 \mathrm{M}, 4 \mathrm{M}$ and $5 \mathrm{M})$, it has been observed that it develops in the salinity range $0 \mathrm{M}-2.5 \mathrm{M}$ (Figure 8). These results 


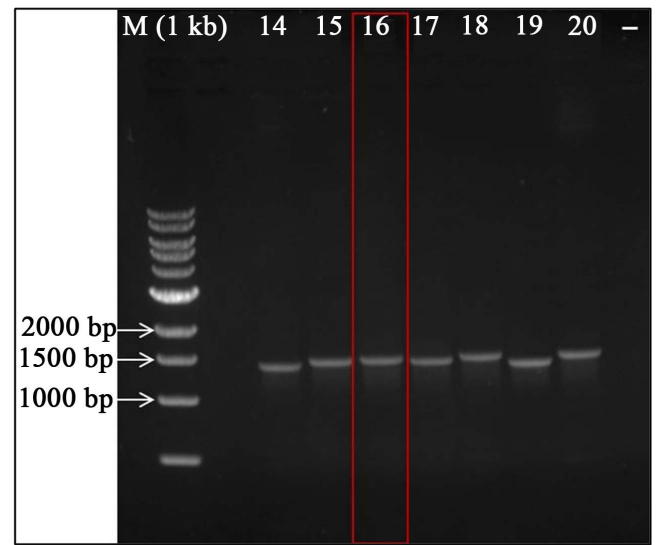

Figure 5. Electrophoresis in $1 \%$ agarose gel of PCR products, obtained through amplification with specific primers for the $16 \mathrm{~S}$ rDNA sequence of the selected bacterial halophilic strain. The red box marks the sample of interest (the cellulolytic strain) and the symbol (-) represents the negative control; samples 14, 15 and $17-20$ represent other non-cellulolytic bacterial strains that were investigated; $M=1 \mathrm{~Kb}$ DNA Ladder; $b p=$ base pair.

ACCTCACCGACTTCGGGTGTTGCAAACTCTCGTGGTGTGACGGGCGGTGTGTACAAGGCCCGGGAACGTATTCACCGCGGCATGCTGATCCGC GATTACTAGCGATTCCAGCTTCACGCAGTCGAGTTGCAGACTGCGATCCGAACTGAGAACAGATTTATGGGATTCGCTAAACCTTGCGGTCTCG CAGCCCTTTGTTCTGTCCATTGTAGCACGTGTGTAGCCCAGGTCATAAGGGGCATGATGATTTGACGTCATCCCCACCTTCCTCCGGTTTGTCAC CGGCAGTCACCTTAGAGTGCCCAACTAAATGCTGGCAACTAAGATCAAGGGTTGCGCTCGTTGCGGGACTTAACCCAACATCTCACGACACGA GCTGACGACAACCATGCACCACCTGTCACTCTGTCCCCGAAGGGAAAGCCCTATCTCTAGGGTTGTCAGAGGATGTCAAGACCTGGTAAGGTT CTTCGCGTTGCTTCGAATTAAACCACATGCTCCACCGCTTGTGCGGGCCCCCGTCAATTCCTTTGAGTTTCAGTCTTGCGACCGTACTCCCCAGG CGGAGTGCTTAATGCGTTAGCTGCAGCACTAAGGGGCGGAAACCCCCTAACACTTAGCACTCATCGTTTACGGCGTGGACTACCAGGGTATCT AATCCTGTTCGCTCCCCACGCTTTCGCTCCTCAGCGTCAGTTACAGACCAGAGAGTCGCCTTCGCCACTGGTGTTCCTCCACATCTCTACGCATTT CACCGCTACACGTGGAATTCCACTCTCCTCTTCTGCACTC

Figure 6. Partial 16S rDNA sequence of the cellulolytic bacterial strain.

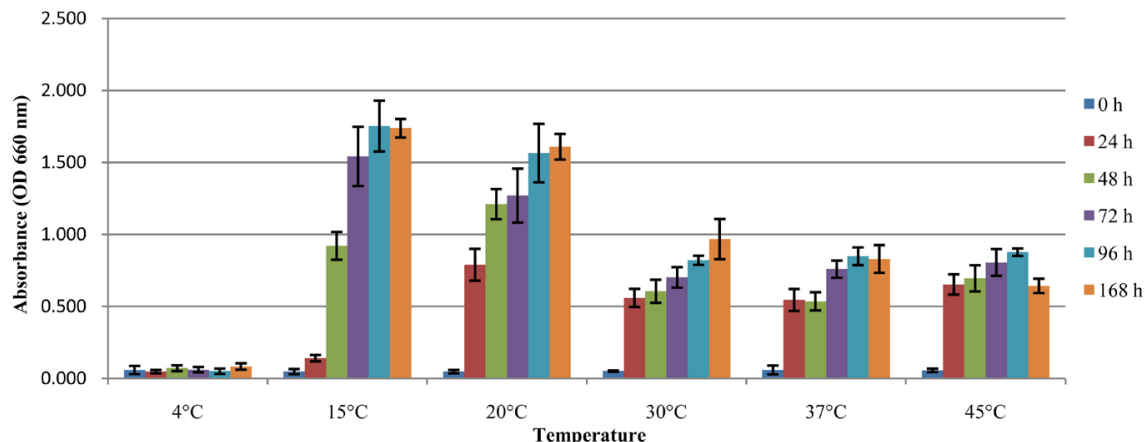

Figure 7. Effects of temperature on growth of the selected bacterial strain.

are confirmed by those obtained by the quantitative experiment (Figure 9). The highest level of turbidity was measured in the culture medium with $2 \mathrm{M} \mathrm{NaCl}$ after $72 \mathrm{~h}$ of incubation. In addition, bacterial growth was also seen in the culture medium with $3 \mathrm{M} \mathrm{NaCl}$ after $144 \mathrm{~h}$ of cultivation. High salt concentrations (3.5 M, $4 \mathrm{M}$ and $5 \mathrm{M}$ ) inhibited bacterial growth in both solid and liquid culture media. Based on the classification scheme proposed by Kushner and Kamekura in 1988 [34], the bacterial strain belongs to the group of extreme halotolerant microorganisms because of its ability to maintain the viability in the presence of $2.5 \mathrm{M}$ salt. 


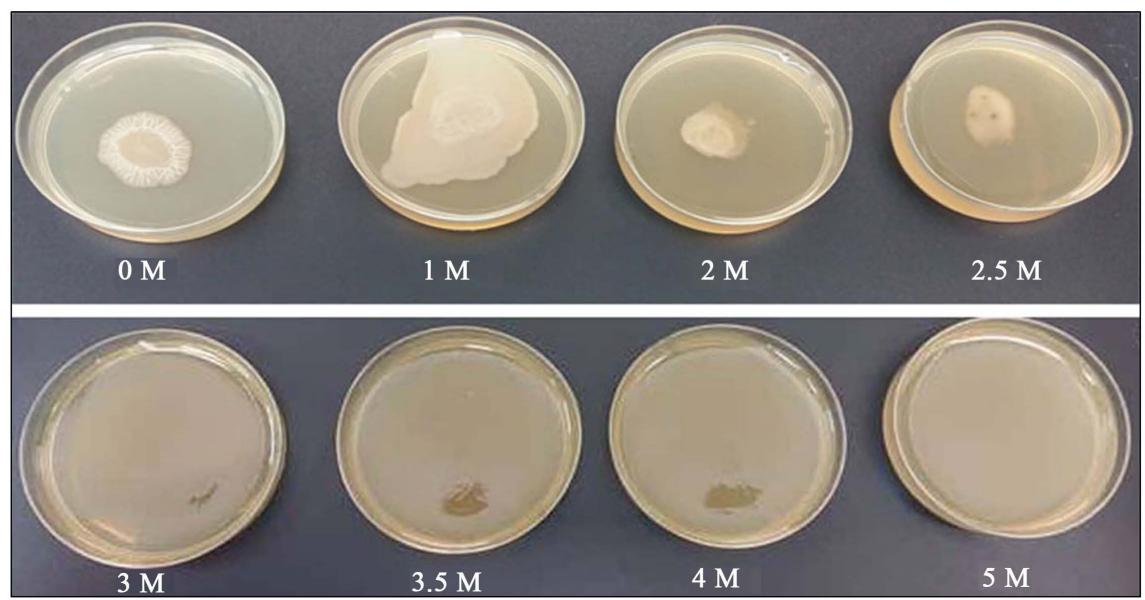

Figure 8. Effects of $\mathrm{NaCl}$ concentration on growth of the selected bacterial strain on solid medium.

The bacterial strain grows on the plates containing $0 \mathrm{M}-2.5 \mathrm{M} \mathrm{NaCl}$; there is no evidence of bacterial growth on the plates containing $3 \mathrm{M}, 3.5 \mathrm{M}, 4 \mathrm{M}$ and $5 \mathrm{M} \mathrm{NaCl}$.

The bacterial strain grows in the $\mathrm{pH}$ range $5-8.5$ and it grows optimally at $\mathrm{pH}$ 7.5, after $96 \mathrm{~h}$ of incubation (Figure 10). Based on these results, the investigated bacterial strain belongs to the group of neutrophilic microorganisms.

Table 3 provides a comparison between the morpho-physiological particularities of the strain B. zhangzhouensis DW5-4 ${ }^{\mathrm{T}}$ [33] and the strain isolated from Movila Miresii Salt Lake.

\subsection{Endoglucanase Activity of the Bacterial Strain}

Regarding the endoglucanase activity of the bacterial strain, the results of the experiment revealed that the intensity of the hydrolytic process is influenced both by variations in salinity of the culture medium and by changes in the thermal values. In addition, the time of cultivation of bacterial cells in the presence of substrate (CMC) is another parameter that influences enzymatic activity. Table 4 lists the most significant endoglucanase activity results, expressed as glucose concentration, under different physicochemical growth conditions (salinity,

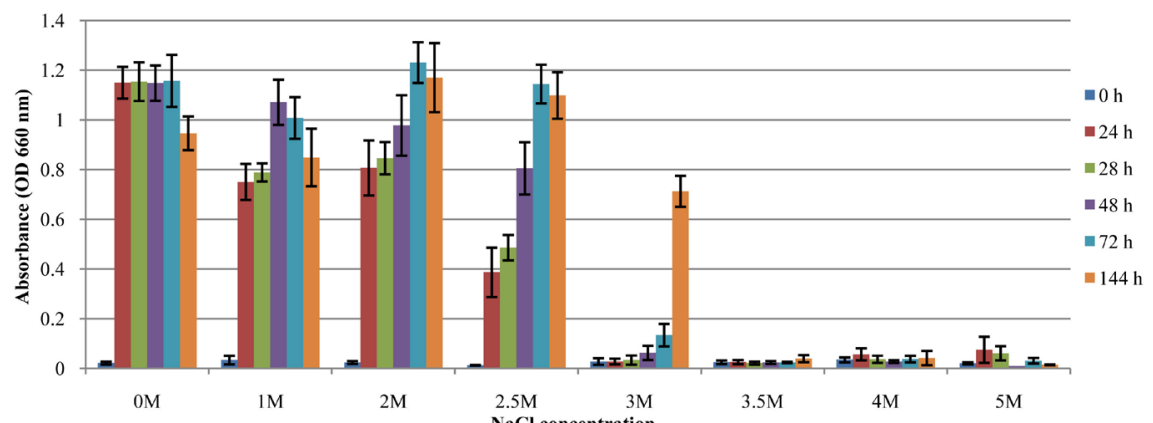

Figure 9. Effects of $\mathrm{NaCl}$ concentration on growth of the selected bacterial strain on liquid medium. 


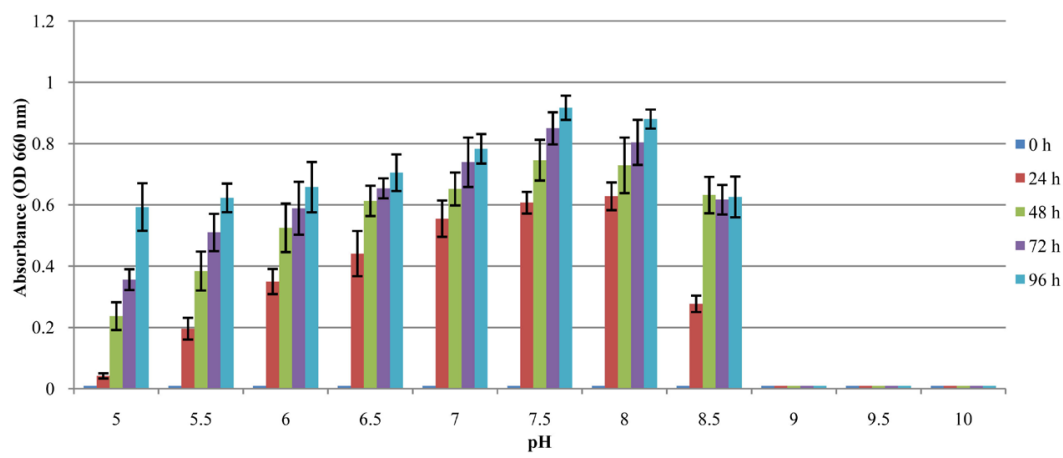

Figure 10. Effects of $\mathrm{pH}$ on growth of the selected bacterial strain.

Table 3. Comparison between the morpho-physiological particularities of the strain $B$. zhangzhouensis DW5-4 ${ }^{\mathrm{T}}$ and the strain isolated from Movila Miresii Salt Lake.

\begin{tabular}{ccc}
\hline Characteristic & $\begin{array}{c}\text { B. } \text { zhangzhouensis } \\
\text { DW5-4 }{ }^{\mathrm{T}}[33]\end{array}$ & $\begin{array}{c}\text { B. } \text { zhangzhouensis-Movila } \\
\text { Miresii Salt Lake }\end{array}$ \\
\hline Colony colour & Cream-white & Cream-white \\
Cell morphology & Rod-shaped & Rod-shaped \\
Motility & Motile & Motile \\
Respiratory metabolism & Aerobic & Aerobic \\
Oxidase & Positive & Positive \\
Catalase & Positive & Positive \\
Temperature $\left({ }^{\circ} \mathrm{C}\right)$ & & $15-45$ \\
Range & $8-45$ & 15 \\
Optimum & $30-37$ & $0-17.5$ \\
NaCl (\%, w/v) & & 11.6 \\
Range & $0-12$ & \\
Optimum & $1-3$ & $5-8.5$ \\
pH & $5-11$ & Negative \\
Range & Negative & Weakly positive \\
Optimum & Weakly positive & \\
Starch hydrolysis & & \\
Lipolytic activity & &
\end{tabular}

Table 4. Determination of glucose content of analysed samples.

\begin{tabular}{ccccc}
\hline Salinity & Temperature & Incubation time & $\begin{array}{c}\text { Absorbance } \\
(\text { OD } 540 \mathrm{~nm})\end{array}$ & $\begin{array}{c}\text { Glucose concentration } \\
(\mathrm{mg} / 0.5 \mathrm{~mL})\end{array}$ \\
\hline $0 \mathrm{M}$ & $37^{\circ} \mathrm{C}$ & $24 \mathrm{~h}$ & 0.044 & 0.97 \\
$1 \mathrm{M}$ & $45^{\circ} \mathrm{C}$ & $24 \mathrm{~h}$ & 0.024 & 0.80 \\
$1 \mathrm{M}$ & $20^{\circ} \mathrm{C}$ & $48 \mathrm{~h}$ & 0.027 & 0.87 \\
$2 \mathrm{M}$ & $15^{\circ} \mathrm{C}$ & $48 \mathrm{~h}$ & 0.096 & 1.25 \\
$2 \mathrm{M}$ & $45^{\circ} \mathrm{C}$ & $72 \mathrm{~h}$ & 0.052 & 1.01 \\
$3 \mathrm{M}$ & $45^{\circ} \mathrm{C}$ & $48 \mathrm{~h}$ & 0.047 & 0.98 \\
$3 \mathrm{M}$ & $20^{\circ} \mathrm{C}$ & $48 \mathrm{~h}$ & 0.088 & 1.21 \\
$3 \mathrm{M}$ & $30^{\circ} \mathrm{C}$ & $48 \mathrm{~h}$ & 0.108 & 1.32 \\
$3 \mathrm{M}$ & $15^{\circ} \mathrm{C}$ & $72 \mathrm{~h}$ & 0.242 & 2.05 \\
$3 \mathrm{M}$ & $20^{\circ} \mathrm{C}$ & $72 \mathrm{~h}$ & 0.048 & 0.99 \\
\hline
\end{tabular}


temperature, incubation time). Although all culture media supplemented with different salt concentrations $(0 \mathrm{M}, 1 \mathrm{M}, 2 \mathrm{M}, 3 \mathrm{M})$ were incubated at different temperatures $\left(15^{\circ} \mathrm{C}, 20^{\circ} \mathrm{C}, 30^{\circ} \mathrm{C}, 37^{\circ} \mathrm{C}, 45^{\circ} \mathrm{C}\right)$, Table 4 presented only the samples in which endoglucanase activity was detected.

The most significant enzymatic activity was detected in the growth medium supplemented with $3 \mathrm{M} \mathrm{NaCl}$, after $72 \mathrm{~h}$ of incubations at $15^{\circ} \mathrm{C}$. In this situation, the amount of glucose released from a volume of $0.5 \mathrm{~mL}$ of CMC substrate $(2 \%$, $\mathrm{w} / \mathrm{v}$ ) is equivalent to $2.05 \mathrm{mg}$.

Analysing the results, it can be deduced that a low sodium chloride concentration $(0 \mathrm{M}$ and $1 \mathrm{M}$ ) limits endoglucanase activity. On the other hand, in the presence of high salt concentrations ( $2 \mathrm{M}$ and $3 \mathrm{M}$ ), endoglucanase activity is more intense and the amount of glucose released is greater.

The temperature value and incubation time of the selected bacterial strain represent two other parameters that influence the intensity of the enzymatic process. For most samples, experimental results indicated that about $48 \mathrm{~h}$ of cultivation are required for a significant enzymatic activity, after which a regression occurs. Reduction of endoglucanase activity, observable for all samples, may be caused by the depletion of the carbon source in the nutrient medium that limits bacterial growth and enzyme synthesis. This can be correlated with the inactivation of cellulolytic enzymes in the physicochemical conditions of the culture medium after a certain amount of time.

\section{Conclusions}

The cellulolytic potential of the halophilic microbial strains isolated from the Movila Miresii Salt Lake is limited. Of the 25 isolates, only one strain demonstrated the ability to hydrolyse carboxymethyl cellulose from the culture medium, the size of the hydrolysis zone being reduced.

Based on molecular identification (16S rDNA sequencing) it has been shown that the cellulolytic isolate belongs to the Bacillus species and is most closely related to Bacillus zhangzhouensis (100\% 16S rDNA gene sequence similarity). Regarding the physiological particularities, the bacterial strain isolated from Movila Miresii Salt Lake is the first reported Bacillus zhangzhouensis strain that exhibits the ability to degrade cellulose and that demonstrates tolerance to high salt concentrations.

The bacterial strain grows optimally at $15^{\circ} \mathrm{C}$ in the presence of $2 \mathrm{M} \mathrm{NaCl}$ concentration at $\mathrm{pH}$ 7.5. The ability of the strain to survive in the presence of high salt concentrations $(3 \mathrm{M} \mathrm{NaCl})$ suggests the existence of an enzymatic equipment that has the property of maintaining its catalytic activity even in harsh conditions of salinity in the industrial environment.

The strain has the ability to synthesize not only cellulases, but also caseinases and lipases. Being stable and active at high salt concentrations, these enzymes synthesised by salt-tolerant microorganisms could play an important role in different biotechnological applications. Consequently, it is necessary to study the 
extremophilic microorganisms and their enzymatic profile to identify such active molecules with new structural and functional properties that can increase the efficiency of some industrial processes.

\section{Conflicts of Interest}

The authors declare no conflicts of interest regarding the publication of this paper.

\section{References}

[1] Credou, J. and Berthelot, T. (2014) Cellulose: From Biocompatible to Bioactive Material. Journal of Materials Chemistry B, 2, 4767-4788. https://doi.org/10.1039/C4TB00431K

[2] Brown, R.M. (2004) Cellulose Structure and Biosynthesis: What Is in Store for the 21st Century? Journal of Polymer Science, Part A: Polymer Chemistry, 42, 487-495. https://doi.org/10.1002/pola.10877

[3] Eyley, S. and Thielemans, W. (2014) Surface Modification of Cellulose Nanocrystals. Nanoscale, 6, 7764-7779.

http://pubs.rsc.org/en/content/articlepdf/2014/NR/C4NR01756K https://doi.org/10.1039/C4NR01756K

[4] Alberts, B., Johnson, A., Lewis, J., Raff, M., Roberts, K. and Walter, P. (2007) Molecular Biology of the Cell. 5th Edition, Garland Science, New York.

[5] Wang, H., Gurau, G. and Rogers, R.D. (2012) Ionic Liquid Processing of Cellulose. Chemical Society Reviews, 41, 1519-1537. https://doi.org/10.1039/c2cs15311d

[6] Obeng, E.M., Adam, S.N.N., Budiman, C., Ongkudon, C.M., Maas, R. and Jose, J. (2017) Lignocellulases: A Review of Emerging and Developing Enzymes, Systems, and Practices. Bioresources and Bioprocessing, 4, 1-22.

https://doi.org/10.1186/s40643-017-0146-8

[7] Gougoulias, C., Clark, J.M. and Shaw, L.J. (2014) The Role of Soil Microbes in the Global Carbon Cycle: Tracking the Below-Ground Microbial Processing of Plant-Derived Carbon for Manipulating Carbon Dynamics in Agricultural Systems. Journal of the Science of Food and Agriculture, 94, 2362-2371. https://doi.org/10.1002/jsfa.6577

[8] Bayer, E.A., Chanzy, H., Lamed, R. and Shoham, Y. (1998) Cellulose, Cellulases and Cellulosomes. Current Opinion in Structural Biology, 8, 548-557. https://doi.org/10.1016/S0959-440X(98)80143-7

[9] Juturu, V. and Wu, J.C. (2014) Microbial Cellulases: Engineering, Production and Applications. Renewable and Sustainable Energy Reviews, 33, 188-203. https://doi.org/10.1016/j.rser.2014.01.077

[10] Li, X. and Yu, H.Y. (2012) Purification and Characterization of an Organic-SolventTolerant Cellulase from a Halotolerant Isolate, Bacillus sp. L1. Journal of Industrial Microbiology \& Biotechnology, 39, 1117-1124. https://doi.org/10.1007/s10295-012-1120-2

[11] Kuhad, R.C., Gupta, R. and Singh, A. (2011) Microbial Cellulases and Their Industrial Applications. Enzyme Research, 2011, 1-10. https://doi.org/10.4061/2011/280696

[12] Behera, B.C., Sethi, B.K., Mishra, R.R., Dutta, S.K. and Thatoi, H.N. (2017) Microbial Cellulases-Diversity \& Biotechnology with Reference to Mangrove Environ- 
ment: A Review. Journal of Genetic Engineering and Biotechnology, 15, 197-210. https://doi.org/10.1016/j.jgeb.2016.12.001

[13] Menendez, E., Garcia-Fraile, P. and Rivas, R. (2015) Biotechnological Applications of Bacterial Cellulases. AIMS Bioengineering, 2, 163-182.

https://www.researchgate.net/publication/280941203

https://doi.org/10.3934/bioeng.2015.3.163

[14] Ventosa, A., Sánchez-Porro, C., Martín, S. and Mellado, E. (2005) Halophilic Archaea and Bacteria as a Source of Extracellular Hydrolytic Enzymes. In: Gunde-Cimerman, N., Oren, A., Plemenitaš, A., Eds., Adaptation to Life at High Salt Concentrations in Archaea, Bacteria, and Eukarya, Springer, Dordrecht, 337-354. https://doi.org/10.1007/1-4020-3633-7_23

[15] Huang, X., Shao, Z., Hong, Y., Lin, L., Li, C., Huang, F., Wang, H. and Liu, Z. (2010) Cel8H, a Novel Endoglucanase from the Halophilic Bacterium Halomonas sp. S66-4: Molecular Cloning, Heterogonous Expression, and Biochemical Characterization. The Journal of Microbiology, 48, 318-324.

https://doi.org/10.1007/s12275-009-0188-5

[16] Asha, B.M. and Sakthivel, N. (2014) Production, Purification and Characterization of a New Cellulase from Bacillus subtilis That Exhibit Halophilic, Alkalophilic and Solvent-Tolerant Properties. Annals of Microbiology, 64, 1839-1848.

https://doi.org/10.1007/s13213-014-0835-x

[17] Ventosa, A., Garcia, M.T., Kamekura, M., Onishi, H. and Ruiz-Berraquero, F. (1989) Bacillus halophilus sp. nov., a Moderately Halophilic Bacillus Species. Systematic and Applied Microbiology, 12, 162-166. https://doi.org/10.1016/S0723-2020(89)80009-8

[18] http://www.sci.muni.cz/ccm/bakterie/html_med/M82.HTM

[19] Teather, R.M. and Wood, P.J. (1982) Use of Congo Red-Polysaccharide Interactions in Enumeration and Characterization of Cellulolytic Bacteria from the Bovine Rumen. Applied and Environmental Microbiology, 43, 777-780. https://www.ncbi.nlm.nih.gov/pmc/articles/PMC241917/

[20] Rohban, R., Amoozegar, M.A. and Ventosa, A. (2009) Screening and Isolation of Halophilic Bacteria Producing Extracellular Hydrolysis from Howz Soltan Lake, Iran. Journal of Industrial Microbiology \& Biotechnology, 36, 333-340. https://doi.org/10.1007/s10295-008-0500-0

[21] Cojoc, R., Merciu, S., Popescu, G., Dumitru, L., Kamekura, M. and Enache, M. (2009) Extracellular Hydrolytic Enzymes of Halophilic Bacteria Isolated from a Subterranean Rock Salt Crystal. Romanian Biotechnological Letters, 14, 4658-4664.

[22] Harley, J.P. and Prescott, L.M. (2002) Laboratory Exercises in Microbiology. Fifth Edition, The McGraw-Hill Companies, New York, 139-140, 161-162, 165-166.

[23] Plou, F.J., Ferrer, M., Nuero, O.M., Calvo, M.V., Alcalde, M., Reyes F. and Ballesteros, A. (1998) Analysis of Tween 80 as an Esterase/Lipase Substrate for Lipolytic Activity Assay. Biotechnology Techniques, 12, 183-186. https://doi.org/10.1023/A:1008809105270

[24] Steel, K.J. (1961) The Oxidase Reaction as a Taxonomic Tool. Journal of General Microbiology, 25, 297-306. https://doi.org/10.1099/00221287-25-2-297 http://www.microbiologyresearch.org/docserver/fulltext/micro/25/2/mic-25-2-297. pdf?expires $=1531208548 \&$ id $=$ id\&accname $=$ guest $\&$ checksum $=87$ A4F86032ED29B9 DB4DBF55A0B75011

[25] Holding, A.J. and Collee, J.G. (1971) Routine Biochemical Tests. In: Norris, J.R. and Ribbonsc, D.W., Eds., Methods in Microbiology, Academic Press Inc., London, 
$1-32$.

[26] Enache, M., Teodosiu, G., Faghi, A.M. and Dumitru, L. (2000) Identification of Halophilic Archaebacteria Isolated from Some Romanian Salts Lakes on the Basis of Lipids Composition. Revue Roumaine de Biologie-Série de Biologie Végétale, 45, 93-99.

[27] Al-Otaibi, D.S., Akbar, A.A., Drobiova, H., Obuekwe, C. and Al-Saleh, E. (2009) Dissemination of Potentially Pathogenic Bacteria into the Environment. In: Brebbia, C.A., Ed., Environmental Health Risk V, Wit Press, 151-159. https://doi.org/10.2495/EHR090151

[28] Enache, M., Itoh, T., Kamekura, M., Teodosiu, G. and Dumitru, L. (2007) Haloferax prahovense sp. nov., an Extremely Halophilic Archaeon Isolated from a Romanian Salt Lake. International Journal of Systematic and Evolutionary Microbiology, 57, 393-397.

http://www.microbiologyresearch.org/docserver/fulltext/ijsem/57/2/393.pdf?expires $=1531218258 \& \mathrm{id}=\mathrm{id} \&$ accname $=$ guest $\&$ checksum $=44598 \mathrm{ABEC} 3 \mathrm{DC} 973 \mathrm{~F} 01831 \mathrm{~F} 670$ CD3EE5F https://doi.org/10.1099/ijs.0.64674-0

[29] Ghose, T.K. (1987) Measurement of Cellulase Activities. Pure and Applied Chemistry, 59, 257-268. https://doi.org/10.1351/pac198759020257

[30] Moldoveanu, M., Florescu, L., Parpală, L., Cojoc, R. and Enache, M. (2015) Romanian Salt Lakes: Some Physical-Chemical Features and Composition of Biological Communities. Oltenia. Studii și comunicări. Științele Naturii, 31, 205-212. http://biozoojournals.ro/oscsn/cont/31_1/25_Moldoveanu.pdf

[31] Păceșilă, I., Cojoc, R. and Enache, M. (2014) Evaluation of Halobacterial Extracellular Hydrolytic Activities in Several Natural Saline and Hypersaline Lakes from Romania. British Biotechnology Journal, 4, 541-550.

http://www.sciencedomain.org/abstract/4471 https://doi.org/10.9734/BBJ/2014/10239

[32] Beebe, J.L. and Wlodkowski, T.J. (1976) Lipids of Branhamella catarrhalis and Neisseria gonorrhoeae. Journal of Bacteriology, 127, 168-178. http://jb.asm.org/content/127/1/168.full.pdf+html

[33] Liu, Y., Lai, Q., Du, J. and Shao, Z. (2016) Bacillus zhangzhouensis sp. nov. and Bacillus australimaris sp. nov. International Journal of Systematic and Evolutionary Microbiology, 66, 1193-1199. https://doi.org/10.1099/ijsem.0.000856

[34] Edbeib, M.F., Wahab, R.A. and Huyop, F. (2016) Halophiles: Biology, Adaptation, and Their Role in Decontamination of Hypersaline Environments. World Journal of Microbiology and Biotechnology, 32, 1-23.

https://doi.org/10.1007/s11274-016-2081-9 